\title{
KESETARAAN GENDER DAN RELASI KUASA \\ DALAM TAFSIR AL-QUR'AN TEMATIK \\ KEMENTERIAN AGAMA REPUBLIK INDONESIA
}

\author{
Tinggal Purwanto \\ IAIN Syaikh Abdurrahman Siddik Bangka Belitung \\ tinggalpurwanto81@gmail.com
}

\section{ABSTRAK}

Kajian ini bertujuan menjelaskan bagaimana relasi kuasa pengetahuan beroperasi dalam Tafsir AlQur'an Tematik, khususnya dalam mengkonstruksi kesetaraan gender. Kajian penelitian ini menemukan bahwa relasi kuasa-pengetahuan mengalir dalam kitab tafsir tersebut. Mufassir tidak hanya berupaya menjelaskan kitab Al-Qur'an semata, tetapi juga berupaya mengkonstruksi kehidupan umat agar sejalan dengan agenda Pemerintah. Mufassir berupaya mengkonstruksi hubungan yang setara antara lakilaki dan perempuan, akan tetapi konstruksi tersebut tidak sepenuhnya obyektif dan netral karena masih menyisakan efek diskriminatif yang lebih memprioritaskan kaum laki-laki di wilayah publik dan kaum perempuan di wilayah domestik. Relasi kusa-pengetahuan ini beroperasi secara sistematis dengan mengontrol hubungan kekuasaan dengan kebenaran sehingga melahirkan kontruksi kesetaraan yang lebih diarahkan untuk mengatur kehidupan umat atas nama peningkatan produktivitas.

Kata kunci: Tafsir Al-Qur'an, Kesetaraan Gender dan Relasi Kuasa. 


\section{ABSTRACT}

This study aims to explain how power-knowledge relations operate in a book, Tafsir Al-Qur'an Tematik, especially in constructing gender equality. The study finds that powerknowledge relations flow in the Tafsir Al-Qur'an Tematik. The power relations operate in a dialectical and productive manner in compiling the tafsir. The mufassir not only try to explain the book of the Qur'an alone, but also attempt to construct the life of the people to be in line with the Government agenda. The mufassir does attempt to construct an equal relationship between men and women, but the construction is not wholly objective and neutral as it still leaves a more discriminatory effect prioritizing men in the public domain and women in the domestic sphere. These power-knowledge relations operate systematically by controlling power relations with truth so as to give rise to more equitable constructions directed to regulate the lives of people on behalf of increased productivity.

Keywords: Tafsir Al-Qur'an, gender equality, and power relations.

\section{A. Pendahuluan}

Kesetaraan dan keadilan gender menjadi isu yang terus bergulir dan diperjuangkan dalam Rancangan Undang-undang Republik Indonesia tentang kesetaraan dan keadilan gender (KKG) sebagai upaya menghapuskan diskriminasi gender di Indonesia. Kesetaraan gender menjadi upaya membangun kesetaraan relasi antara perempuan dan laki-laki dalam dalam mengakses berbagai informasi, berpartisipasi di segala bidang, mengontrol dan memperoleh manfaat pembangunan serta sebagai media memperjuangkan hak asasi manusia. Rendahnya partisipasi perempuan dalam pembangunan dan masih banyaknya praktek diskriminasi gender yang terjadi dalam masyarakat ditengarai menjadi alasan mengapa kesetaraan 
gender harus diperjuangkan. Kesenjangan partisipasi kaum perempuan di bidang politik, ekonomi, sosial, pendidikan, dan lain-lain akibat penafsiran atas ajaran agama yang bias gender menyebabkan ketimpangan struktur sosiokultural perempuan dalam bermasyarakat, berbangsa dan bernegara. Kesenjangan ini membatasi akses sebagian besar perempuan untuk mendapatkan layanan kesehatan yang lebih baik, pendidikan yang lebih tinggi, dan partisipasi dalam kegiatan publik yang lebih luas.

Posisi perempuan yang masih belum optimal di atas mendorong para aktivis perempuan dan Pemerintah Indonesia untuk mengentaskan perempuan dari keterbelakangan. Berbagai upaya dilakukan oleh Pemerintah Indonesia dalam memberdayakan perempuan, di antaranya membentuk kementerian yang khusus menangani perempuan. Keseriusan Pemerintah dalam menangani perempuan ini tampak jelas ketika dibentuk Komisi Nasional (Komnas) Perempuan berdasarkan Keputusan Presiden Nomor 181/1998 sebagai lembaga independen yang bertugas menghapuskan kekerasan terhadap perempuan. Puncaknya, diterbitkannya UU No. 23 tahun 2004 tentang penghapusan Kekerasan dalam Rumah Tangga (KDRT) menjadi motivator kesetaraan gender di Indonesia.

Keseriusan Pemerintah juga terlihat dalam upayanya mewacanakan kesetaraan gender melalui Tafsir Al-Qur'an. Dengan Tafsir Al-Qur'an, dialektika produktif dan kreatif antara nalar mufassir, teks AlQur'an dan konteks masyarakatmenurut ar-Rumi (2002)dapat melahirkan produk tafsir yang sejalan dengan perkembangan zaman, yang dinamis dan 
signifikan sesuai dengan ideologi, kecenderungan, metodologi dan teori yang dikembangkan para mufassir dalam memahami Al-Qur'an (Al Munawar, 2002:61-93). sehingga tafsir Al-Qur'an tidak kehilangan momentumnya dalam merespons realitas persoalan sosial keagamaan yang senantiasa berkembang di masyarakat (Shihab, 2005: 33).

Tafsir Al-Qur'an merupakan produk budaya yang di dalamnya memuat unsur-unsur yang saling terkait dan saling mempengaruhi antar berbagai kepentingan pada diri mufassir. Meminjam pendapatFoucault (1980), kepentingan penguasa terkadang secara tidak disadari masuk ke dalam proses penafsiran. Di satu sisi, agenda Pemerintah Republik Indonesia dalam memproduksi kitab Tafsir AlQur'an menunjukkan perannya dalam menyebarluaskan nilai-nilai Islam kepada masyarakat (Federspiel, 1996: 143144). Di sisi lain, agenda tersebut menurut Basuni dalam sambutannya pada penerbitan Tafsir Al-Qur'an Tematik (Kemenag RI, 2014: 09) menyatakan bahwa penerbitan tersebut merupakan upaya mengatur perilaku kehidupan umat Islam dalam bermasyarakat, berbangsa dan bernegara sekaligus serta mengawal pemahaman teks keagamaan agar tetap benar dan baik serta terhindar dari segala bentuk penyelewengan.

Keterlibatan Pemerintah dalam penyusunan kitab Tafsir Al-Qur'an Tematik menimbulkan problematika dan memunculkan beragam pertanyaan terkait dengan berbagai kepentingan. Keterlibatan tersebut mengindikasikan adanya relasi kuasa pemerintah terhadap kitab tafsir tersebut, khususnya dengan tema-tema kesetaraan gender yang berbicara tentang pemberdayaan perempuan, kedudukan dan peran perempuan (Kemenag RI, 2014: 282-302), serta perempuan dan ketenagakerjaan (Kemenag 
RI, 2014: 273-291). Di satu sisi, tema-tema gender tersebut dapat dipahami sebagai bentuk pengakuan pada eksistensi perempuan sebagai manusia, sekaligus juga sebagai media dakwah tentang pentingnya kesetaraan gender di bidang sosial, ekonomi, pendidikan dan kesehatan di era modern ini. Di sisi lain, keterlibatan Pemerintah-meminjam istilah Foucaut--adalah relasi-kuasa pengetahuan melalui wacana yang terkadang tidak disadari telah mendominasi, menghegemoni, mengontrol dan mengarahkan perilaku setiap individu (Foucault, 1990: 92-83). Hal ini yang mendasari mengapa perlu dilakukan kajian terhadap tafsir Al-Qur'an yang mewacanakan kesetaraan gender.

Kajian gender dalam tafsir Al-Qur'an pernah dilakukan oleh Nasarudin Umar, dalam bukunya Argumen Kesetaraan Jender Perspektif Al-Qur'an (1999), dengan pendekatan ilmu-ilmu sosial, linguistik dan hermeneutik, berupaya mengungkap ayat-ayat Al-Qur'an yang bernuasa gender. Zaitunah Subhan melalui karyanya Tafsir Kebencian: Studi Bias Gender dalam Tafsir Al-Qur'an (1999) dengan pendekatan tafsir maudhu'i meneliti kemitrasejajaran pria dan wanita. Yunahar Ilyas dalam karyanya Konstruksi Pemikiran Gender dalam Pemikiran Mufassir (2005), dengan pendekatan tafsir-hermeneutis dan teologis-filosofis meneliti skema dan paradigm tafsir Indonesia tentang kesetaraan laki-laki dan perempuan. Penelitian lain berjudul "Hubungan kekuasaan-Pengetahuan dalam "Pewacanaan Ulu al-Amr QS.an-Nisa [4]: 59 Pada Tafsir alAzhar: Memotret Diskusi Dasar Negara Indonesia Tahun 1955-1966" karya Ulya (2016). Penelitian ini menemukan wacana Ulu al-Amr dalam Tafsir al-Azhar tidak netral dan subyektif, tetapi sarat dengan strategi kekuasaan.

Berangkat dari survei literatur, kajian ini menemukan signifikansinya. Artikel ini memfokuskan kajian pada 
bagaimana kesetaraan gender dan relasi kuasa dikonstruksi dalam Kitab Tafsir Al-Qur'an Tematik dengan pendekatan hermeneutik. Dengan meneliti konstruksi kesetaraan gender, artikel ini memfokuskan pada kesetaraan hakhak gender yang dikontruksi di dalam kitab tersebut. Selanjutnya dengan meneliti relasi kuasa, artikel ini akan memfokuskan pada wacana tafsir yang dikonstruksi sebagai norma atau aturan dalam bersikap dan berperilaku yang dianggap mampu menyetarakan hubungan antara laki-laki dan perempuan dengan keanekaragaman bentuk dan hubungan.

\section{B. Pembahasan}

\section{Konstruksi Kesetaraan Hak Gender dalam Tafsir Al- Qur'an Tematik}

Gender merupakan sebuah realitas sosial yang dikonstruksi oleh struktur keyakinan, sosial, ekonomi, dan politik tertentu. Realitas sosial ini dikonstruksi secara kolektif berdasarkan kesepakatan dan konvensi yang termanifestasi dalam bahasa dan proses interaksi sosial maupu lainnya (Dzuhayatin, 2015: 7-8). Sedangkan kesetaraan gender dipahami oleh Lemer dkk. (2006: 3) sebagai sebuah konstruksi sosial-budaya terhadap lakilaki dan perempuan yang menuntut suatu keadaan yang setara antara laki-laki dan perempuan dalam pemenuhan hak dan peningkatan kualitas hidup. Kesetaraan gender menuntut setiap individu, kelompok, maupun komunitas diperlakukan sejajar (equal standing) dan mendapat penghormatan yang setara (equal respect). Kesetaraan ini dipertegasjuga oleh Wienclaw (2011: 15) yang menyatakan bahwa meskipun jenis kelamin laki-laki dan perempuan itu berbeda namun keduanya setara dalam kedudukan dan 
perannya.

Secara khusus, Jawad (1998: 7-11) menegaskan bahwa ada 8 (delapan) hak perempuan yang harus disetarakan, meliputi: hak kepemilikan yang independen, hak untuk menikah dengan orang yang disukai dan mengakhiri pernikahan yang gagal, hak untuk memperoleh pendidikan, hak untuk menjaga identitasnya, hak untuk memperoleh kenikmatan seksual, hak memperoleh warisan, dan hak untuk mengikuti pemilu, nominasi memperoleh jabatan politik dan partisipasi dalam urusan publik. Demikian pula, Mulia (2005: 227-228) yang secara spesifik lagi merumuskan hak-hak yang harus didapatkan perempuan sebagai istri, meliputi: hak atas perlakuan baik dan terbebas dari segala bentuk kekerasan, baik fisik, seksual, maupun psikis; hak atas nafkah, baik lahir maupun bathin; hak kepemilikan dan pengelolahan harta pribadi; hak kepemilikan dan pengelolahan harta bersama; hak melakukan tugas domestik bersama; hak mengugat cerai; dan hak atas harta waris.

Dengan menjadikan kitab Tafsir Al-Qur'an Tematik sebagai objek kajian, artikel ini memfokuskan pembahasan pada bagaimana kesetaraan gender dikonstruksi dalam kitab tersebut dan pada saat yang sama bagaimana relasi kuasa-pengetahuan beroperasi dalam konstruksi kesetaraan gender tersebut. Beberapa topik kesetaraan gender yang akan dikaji dalam artikel ini meliputi: kesetaraan bekerja dan perlindungan kerja, kesetaraan kemandirian ekonomi, kesetaraan pendidikan tinggi, kesetaraan hidup sehat, dan kesetaraan hak kepemimpinan.

\section{a. Kesetaraan hak bekerja dan perlindungan kerja}

Islam memberikan kebebasan yang begitu besar 
kepada perempuan sebagaimana laki-laki untuk berkiprah di ruang publik. Kiprah di ruang publik dilatarbelakangi sejumlah faktor yang mendorong perempuan untuk bekerja dan mengembangkan bakatnya(Kemenag RI, 2014: 284.) dan mengaktualisasikan dirinya dengan pengetahuan, inisiatif, dan keterampilan yang dimilikinya guna mendapatkan kemandirian ekonomi yang mapan (Subhan, 1999: 158).

Terkait dengan hak bekerja, Tafsir Al-Qur'an Tematik melalui tema "Perempuan dan Ketenagakerjaan" mengkonstruksi sebuah pengetahuan bahwa perempuan memiliki peluang yang sama dengan laki-laki untuk berpartisipasi dalam meningkatkan perekonomian. Tidak ada larangan bagi perempuan untuk bekerja meski sudah dinafkahi oleh laki-laki, bahkan ketiadaan anggota laki-laki atau ada anggota laki-laki tetapi tidak mampu mencukupi kebutuhan primer keluarga, menjadi alasan kuat bagi perempuan untuk lebih produktif dalam memenuhi kebutuhan hidupnya (Kemenag RI, 2014: 295). Setiap individu, baik perempuan atau pun laki-laki harus terbebas dari kemiskinan dan mendorongnya menuju kemandirian ekonomi (Kemenag RI, 2014: 296). Dalam konteks seperti ini, pendidikan tinggi memainkan peran penting dalam meningkatkan ekonomi perempuan. Mengingat selama ini, pendidikan yang rendah ditengarai menjadi faktor penyebab ketidaksetaraan ekonomi antara perempuan dengan laki-laki (Wienclaw, 2011:129)

Dalam hak ketenagakerjaan, Tafsir Al-Qur'an Tematik (Kemenag RI, 2014: 276) membangun pengetahuan bahwa perempuan memiliki hak yang setara dengan laki-laki untuk memasuki berbagai profesi sesuai dengan keahliannya, bahkan bila ia mampu dan 
memenuhi kriteria sebagai top leader boleh menjadi perdana menteri, atau menjadi kepala negara karena pada hakekatnya agama Islam tidak menghalangi asalkan dalam tugasnya tetap memperhatikan hukumhukum atau aturan-aturan yang telah ditetapkan oleh Islam, namun keterlibatan perempuan di dunia kerja tidak serta merta melepaskan dirinya dari urusan keluarga. Perempuan tidak boleh menelantarkan urusan dan tugasnya dalam rumah tangga, perempuan harus mendapat izin atau persetujuan dari suaminya, dan pekerjaan tersebut tidak mendatangkan hal yang negatif terhadap diri dan agamanya.

Konstruksi yang dibangun di atas pada satu sisi memang memberikan akses kepada perempuan untuk mengaktualisasikan diri dengan berkarir, namun pada sisi lain perempuan juga dibebani dengan dua tanggung jawab sekaligus (keluarga dan pekerjaan) dalam meraih kesempatan, dan pada saat yang sama menurut Subhan (1999: 164) dituntut untuk menjaga keharmonisan dalam menjalani kehidupan rumah tangga dan pekerjaan.

Tafsir Al-Qur'an Tematik membangun pengetahuan tentang kesetaraan hak setiap individu, baik perempuan ataupun laki-laki dalam meraih pekerjaan dan penghidupan yang layak. Dalam konteks Keindonesiaan, UUD 1945 pasal 27 ayat 2 telah menetapkan bahwa "Tiap-tiap warga negara berhak atas pekerjaan dan penghidupan yang layak bagi kemanusiaan." Kebijakan pemerintah Indonesia dalam UU No. 13 tahun 2003 tentang ketenagakerjaan. Secara umum, Pemerintah memberikan perlindungan tenaga kerja meliputi hak berserikat dan berunding bersama, keselamatan kerja dan kesehatan kerja, dan jaminan sosial tenaga kerja. Perlindungan kerja di Indonesia yang berlaku secara 
umum, tidak membedakan jenis kelamin.Disebabkan perempuan memiliki fungsi reproduksi yang lebih rumit, maka diperlukan perlindungan khusus bagi perempuan sebagai upaya untuk mencapai hasil kerja yang optimal dan sejajar dengan kaum laki-laki (Kemenag RI, 2014: 283)

Pendapat Tafsir Al-Qur'an Tematik (Kemenag RI, 2014: 52) yang membolehkan perempuan beraktivitas di luar rumah, secara implisit, telah mendekonstruksi penafsiran-penafsiran kontra produktif yang selama ini mengekang potensi perempuan dengan menjadikan Al-Qur'an sebagai justifikasi untuk melanggengkan dominasi laki-laki terhadap perempuan. Kesetaraan gender memberikan kontribusi kepada semua jenis kelamin dalam kehidupan sosial kemasyarakatan atau untuk meningkatkan taraf kehidupannya menjadi lebih baik dengan segala potensi dan talenta yang dimilikinya. Dalam konteks ini, Tafsir Al-Qur'an Tematik berusaha menyalurkan dan mengatur wacananya agar sesuai dengan tuntutan perkembangan zaman dan dapat diterima oleh masyarakat sebagai kebenaran ilmiah serta diakui sebagai penafsiran yang memiliki otoritas di masyarakat.

Tafsir Al-Qur'an Tematik (Kemenag RI, 2014: 284.) mengekspose sejumlah faktor yang menuntut perempuan untuk bekerja di sektor publik, di antaranya: pendidikan tinggi, kebutuhan ekonomi, melepaskan ketergantungan terhadap suami, mencari kekayaan sebanyak-banyaknya, mengisi waktu lowong, mencari ketenangan dan hiburan, serta mengembangkan bakat. Faktor-faktor tersebut menurut Song (2007: 41) menunjukkan bahwa perempuan memiliki kebutuhan primer sekaligus sekunder yang hanya dapat dipenuhi 
dengan bekerja di sektor publik, bersamaan dengan itu perempuan berhak untuk hidup layak. Sependapat pula dengan pendapat Schneider (2009: 378) yang menegaskan bahwa perempuanberhak meningkatkan taraf hidupnya menjadi lebih baik.

Tafsir Al-Qur'an Tematik membangun wacana yang menghubungkan perempuan bekerja dengan pendidikan tinggi, kemandirian ekonomi, dan pengembangan bakat (Kemenag RI, 2014: 284).Dalam konteks ini, menguitip pendapat Mosse (1996: 46) telah terjadi pergeseran pola pikir yang sebelumnya menempatkan perempuan hanya sebagai ibu dengan tugas mengasuh anak dan mengurus rumah tangga digeser dengan pola pikir yang menempatkan perempuan sebagai pencari nafkah.

\section{b. Kesetaraan Hak Kemandirian Ekonomi}

Hak kepemilikan sangat diperhatikan dalam Islam. Tafsir Al-Qur'an Tematik (Kemenag RI, 2014: 139-140) membangun pandangan bahwa perempuan memiliki 2 (dua) hak kepemilikan: kepemilikan yang bersifat pribadi (individual) dan kepemilikan yang bersifat kolektif.Kepemilikan yang bersifat pribadi adalah semua hak kepemilikan perempuan yang diperoleh dari harta warisan dari keluarganya yang mewariskan (QS. an-Nisa'[4]: 11), hasil usaha atas pekerjaannya, dan pemberian yang bersifat khusus, seperti mahar (maskawin) (QS. an-Nisa' [4]: 4). Sedangkankepemilikan yang bersifat kolektif atau bersama, yaitu kepemilikan antara istri dengan suaminya yang diperoleh selama pernikahan. Dalam konteks ini, menurutEngineer sebagaimana dipahami Rohmaniyah (2014: 118), sebenarnyaperempuan lebih diuntungkan karena mendapat hak kepemilikan yang lebih banyak dari 
laki-laki. Dominasi bahkan bisa terjadi sebaliknya, perempuan mendominasi laki-laki karena kepemilikan hartanya (Dzuhayatin, 2015: 135-136)

Hakkemandirianekonomi yang dikonstruksi Tafsir Al-Qur'an Tematiksejalan dengan pendapat Mulia (2005: 229) yang menyatakan bahwa kemandirian ekonomi dianggap bagiandari kesetaraan gender yang memberikan perlakuan yang setara tanpa membedakan jenis kelamin.Demikian pula pendapat Grown (2005:78) yang menyatakan bahwa Perempuan dan laki-laki samasama dapat memiliki dan membelanjakan hartanya sesuai kehendaknya sehingga tidak terjadi kesenjangan disebabkan status hak properti yang berbeda antara perempuan dengan laki-laki.

Tafsir Al-Qur'an Tematik dengan wacana pemberdayaan ekonomi membangun pengetahuan tentang legitimasi Al-Qur' an terhadap perempuan untuk mendapatkan hak ekonomi yang tidak boleh dilanggar oleh kaum laki-laki, meliputi: hak atas mahar, hak waris, hak nafkah, dan hak bekerja sama. Relasi kekuasaan ada di balik wacana pemberdayaan ekonomi perempuan. Relasi ini meminjam pendapat Foucault (1977: 141) telah memunculkan mekanisme pendisiplinan yang mengarahkan laki-laki dan perempuan menuju produktivitas. Hal ini terlihatdari adanya pengarahan pada penafsiran bahwa "Semestinya laki-laki dan perempuan sama-sama didorong untuk mandiri secara ekonomi, agar keluarga muslim tidak mudah jatuh miskin lalu terdorong pada kekafiran" (Kemenag RI, 2014: 296). Hal ini tentu saja meniscayakan adanya pergeseran pengetahuan dalam pembagian peran mencari nafkah yang sebelumnya berada di tangan laki-laki namun dengan adanya wacana yang dimunculkan tersebut 
menyebabkan terjadinya pergeseran pengetahuan peran mencari nafkah berada di kedua pihak, baik lakilaki maupun perempuan. Dalam pandangan Foucault, sebagaimana diungkapkan Mudhoffir (2013: 81), pengetahuan mengalami pergeseran dari satu bentuk pengetahuan ke bentuk pengetahuan lain yang otoratif pada masa tertentu sebagai sebuah rezim wacana.

\section{c. Kesetaraan Hak Pendidikan Tinggi}

Pendidikan memiliki arti penting sebagai sarana untuk melakukan perubahan sosial. Pendidikan yang rendah menurut Wienclaw (2011: 129) disinyalir menjadi salah satu faktor ketidaksetaraan ekonomi perempuan dengan laki-laki. Bahkan turunnya kehormatan perempuan tidak disebabkan oleh keterbukaan atau ketertutupan aurat, tetapi ditentukan oleh pendidikan yang baik ataupun yang buruk (Zayd, 2003: 156).

Terkait dengan hak pendidikan, Tafsir Al-Qur'an Tematik(Kemenag RI, 2014: 297) membangun pandangan bahwa perempuan berhak mendapatkan prioritas hak pendidikan yang tinggi di tengah kecenderungan masyarakat yang mengabaikan hak tersebut. Masih minimnya jumlah perempuan yang duduk dalam posisi strategis pengambil kebijakan publik dan kebutuhan akan tenaga-tenaga profesional perempuan menjadi alasan kuat mengapa perempuan berhak atas pendidikan yang tinggi,bahkan sejak dari dari buaian hingga akhir hayat (Jawad, 1988: 20).

Tafsir Al-Qur'an Tematik (Kemenag RI, 2014: 59) membangun pandangan berdasarkan QS. Al-Baqarah [2]: 30-31 bahwa untuk suksesnya tugas kekhalifahan manusia di muka bumi bukan hanya monopoli bagi kaum laki-laki melainkan juga bagi kaum perempuan. 
Allah SWT menganugerahkan potensi kepada lakilaki juga kepada perempuan untuk dapat mengetahui dan memahami segala sesuatu yang bermanfaat bagi kehidupannya.

Pendidikan tinggi dapat menentukan pola pikir, sikap dan perilaku perempuan. Melalui pendidikan tinggi, perempuan diharapkan lebih dapat memberi respon terhadap situasi lingkungan (Mulia, 2005: 240). Demikian pula menurut Jawad (1998: 20-21), perempuan dapat mengembangkan intelektualitasnya, memperluas pandangannya, menumbuhkan bakatnya dan kemudian memanfaatkan potensinya untuk kemaslahatan diri dan masyarakatnya serta berperan aktif di berbagai bidang pembangunan sosial, ekonomi dan politik.

\section{d. Kesetaraan Hak Hidup Sehat}

Kesetaraan hak hidup sehat dapat ditelusuri melalui kesetaraan hak reproduksi, kesetaraan hak berolahraga dan kesetaraan hak berbusana. Reproduksi memiliki arti penting bagi laki-laki dan perempuan guna menjaga kelangsungan kehidupan manusia. Tafsir Al-Qur'an Tematik (Kemenag RI, 2014: 298-299) membangun pandangan kesetaraan hak kesehatan reproduksi bagi semua jenis kelamin. Atas dasar fungsi utamanya untuk melestarikan kehidupan manusia melalui reproduksi, perempuan harus diprioritaskan kesehatannya. Perempuan harus dilindungi kesehatannya dengan cara yang sah, yakni pernikahan sebagai upaya melindungi alat reproduksi perempuan dari hubungan seksual di luar nikah. Perempuan juga mempunyai hak melindungi diri dari alat kelamin yang kemungkinan terjangkit virus 
akibat melakukan hubungan seksual secara bebas.

Tafsir Al-Qur'an Tematik (Kemenag RI, 2014: 300) juga membangun pengetahuan tentang hak kesehatan reproduksi bagi perempuan. Perempuan berhak mendapat jaminan sosial bagi terpenuhinya kebutuhan primer perempuan seperti: hamil, melahirkan, dan menyusui terutama perempuanperempuan miskin; perempuan berhak mendapat akses untuk mengetahui seluk-beluk kesehatan perempuan dan bagaimana menjaganya; perempuan berhak atas kemudahan akses untuk menjangkau tenaga ahli, sarana dan prasarana melahirkan yang memadai terutama jika terdapat kelainan dalam kandungan; perempuan berhak mendapat cuti hamil, melahirkan, dan menyusui bagi perempuan, terutama bagi mereka yang menjadi tumpuan ekonomi keluarga.

Tafsir Al-Qur'an Tematik menunjukkan andilnya memperjuangkan hak-hak kesehatan reproduksi. Dalam konteks ini, penafsiran tersebut menjadi instrumen untuk menyampaikan hak-hak kesehatan reproduksi, utamanya bagi perempuan yang kadangkadang terabaikan tersebut. Di sisi lain, wacana kesetaraan hak kesehatan reproduksi yang dibangun tersebut menjadi counter ideology (ideologi tandingan) bagi kondisi perempuan yang terbelit kemelut persoalan diskriminasi gender.

Tafsir Al-Qur'an Tematik (Kemenag RI, 2014: 300) memberikan otoritas kepada perempuan agar dapat menyetarakan diri dengan laki-laki dalam memperhatikankondisi fungsi reproduksinya, sehingga tidak diabaikan. Dalam konteks ini, solusi 
konkret diwacanakan dengan cara memaksimalkan pemberdayaan perempuan di bidang kesehatan. Dari sini kesetaraan kesehatan melahirkan pandangan tentang pentingnya kesehatan tidak hanya bagi kaum laki-laki tetapi juga bagi kaum perempuan. Kesetaraan kesehatan juga dengan sendirinya dapat menciptakan efek kekuasaan yang menuntut fasilitasfasilitas kesehatan lainnya; yang menunjang hakhak kesehatan reproduksi laki-laki dan perempuan (Mulia, 2005:236).

Olah raga memberikan kontribusi besar bagi kesehatan tubuh agar tetap sehat dan bugar, baik bagi laki-laki maupun perempuan. Tafsir AlQur'an Tematik(Kemenag RI,2014: 64) membangun pandangan bahwa perempuan dan laki-laki memiliki kesempatan yang sama untuk beraktivitas di bidang olah raga apapun cabangnya. Kendatipun demikian, norma-norma agama terkait dengan pakaian olahraga yang dikenakan dan jenis olah raga yang diminati harus tetap diperhatikan ketika beraktivitas di bidang olah raga.

Tafsir Al-Qur'an Tematik (Kemenag RI, 2014: 65) mewacanakan pengetahuan tentang spirit Al-Qur'an dalam memberikan pembatasan aktivitas terhadap kaum perempuan dan laki-laki dalam berolahraga bukan didasarkan pada kesan membatasi aktivitas, tetapi diletakkan dalam konteks memberikan petunjuk untuk menyempurnakan peran yang disandangnya. Relasi kuasa memainkan peran yang dominan dalam hak berolahraga. Relasi kuasa ini terjadi antara mufassir dengan masyarakat dan negara dengan masyarakat. Mufassir menghendaki masyarakat menjalani hidup dengan baik sesuai dengan ajaran 
agama, sementara negara menghendaki warga negara yang hidup sehat dan pada saat yang sama pemerintah menuntut produktivitas dari masyarakat, baik laki-laki maupun perempuan.

Hak berbusana yang setara dapat ditemukan dalam pembahsan tafsir Tematik ini ketika busana dimaknai sebagai pakaian penutup aurat. Tafsir AlQur'an Tematik (Kemenag RI, 2014: 68) menjelaskan bahwa kata "aurat" berasal dari 'awira artinya hilang perasaan, yakni tidak baik dipandang, memalukan, dan mengecewakan. Kata "aurat" juga berasal dari 'ara artinya menutup dan menimbun, yakni sesuatu yang ditutup hingga tidak dapat dilihat dan dipandang. Selanjutnya kata "aurat" bisa juga berasal dari kata a'wara yakni sesuatu yang jika dilihat akan mencemarkan. Kata aurat tersebut dalam hukum Islam selanjutnya dipahami sebagai batas minimal dari bagian tubuh yang wajib ditutup karena perintah Allah. Oleh karenanya, aurat adalah suatu anggota yang harus ditutup dan dijaga hingga tidak menimbulkan kekecewaan dan malu.

Busana bisa juga dimaknai sebagai alat pelindung tubuh dari cuaca alam yang keras dan pelindung dari lingkungan sosial yang negatif (Crawley,1931:8). Terkait dengan busana, Tafsir AlQur'an Tematik(Kemenag RI, 2014: 70) membangun pengetahuan tentang keharusan busana muslimah bagi perempuan. Menurutnya, perempuan muslim wajib berbusana muslimah berdasarkan QS. alAhzab [53]: 33 dan QS. an-Nur[24]: 31. Demikian pula dengan pemakaian jilbab, perempuan berjilbab/ berkerudung identik dengan perempuan yang baik dan terhormat, sedangkan perempuan yang 
tidak memakai jilbab/kerudung dinilai sebagai perempuan tidak terhormat dan tidak bermoral (Kemenag RI, 2014: 67). Dalam konteks ini, menurut El-Guindi (1999:109), jilbab menjadi sarana mengkomunikasikanidentitasseorangperempuan sebagai muslimah sekaligus menjadi identitas kesalehan seorang perempuan.

Terkait dengan aktivitas yang memerlukan penyesuaian, Tafsir Al-Qur'an Tematik (Kemenag RI,2014: 79) juga membangun pandangan bahwa dalam kondisi darurat, perempuan diperbolehkan membuka anggota badan tertentu, sekedar yang diperlukan, karena profesi tertentu, misalnya bekerja di sawah atau sebagai pembantu rumah tangga. Kebolehan ini berlaku pula perempuan yang dalam aktivitasnya mengharuskan untuk memakai lambang atau tanda pangkat kedinasan di bahunya. Mode pakaian bisa disesuaikan dengan selera masingmasing, asalkan tidak keluar dari kriteria kesopanan (Kemenag RI, 2014: 82-83). Dalam konteks ini, menurut Rohmaniyah (2014: 121), busana muslimah tidak hanya dipahami secara normatif sebagai pakaian yang menutupi seluruh tubuh kecuali muka dan telapak tangan, tetapi juga dipahami secara kontekstual ketika dalam kondisi yang menuntut penyesuaian. Perempuan muslimah diidentifikasi dengan model busana yang dianggap sesuai dengan norma-norma agama Islam. Meski di dunia Barat, menurut El-Guindi (1999: 36), kata veil (jilbab) mengandung citra yang menyudutkan Islam bahkan disandingkan dengan kata poligami karena unsur melemahkan dan penindasan terhadap perempuan. Penggunaan jilbab itu sendiri merupakan bagian dari kekuasaan dalam pengaturan seksualitas perempuan 
dengan kewajiban berbusana muslimah. Meminjam pandangan Foucault (1977: 27, 141), kekuasaan tersebut telah menghegemoni sampai ke tingkat yang paling intim, yakni pengaturan seksualitas perempuan dengan kewajiban berbusana muslimah. Pengaturan seksualitas seperti ini dapat dikategorikan sebagai salah satu bentuk pendisiplinan guna memaksimumkan dan meningkatkan produktivitas, serta mencegah timbulnya kejahatan dengan mengontrol setiap individu, menormalisai tubuh agar patuh, produktif, dan terhindar darihal-hal yang negatif.

\section{e. Kesetaraan Hak Kepemimpinan: Domestik- Publik}

Tafsir Al-Qur'an Tematik(KemenagRI,2014:36-37) mengkonstruksi kesetaraan kepemimpinan domestik dengan menyebutnya sebagai kepemimpinan kolektif antara perempuan dengan laki-laki; kepemimpinan yang saling menguatkan fungsi keduanya; dan kepemimpinan yang saling mengutamakan kewajiban dibanding dengan menuntut hak-haknya. Pola hidup berumah tangga diatur dan diminimalisir dari konflik antara suami-istri, sehingga terbangun keluarga yang kokoh, kuat, dan sejahtera (keluarga sakinah)." Pengaturan pola hidup berumah tangga ini, dalam pandangan Foucault (1977: 212), telah membangun relasi-kuasa yang terkadang tidak disadari telah mendominasi, menghegemoni, mengontrol dan mengarahkan perilaku setiap individu.Dalam sudut pandang inilah, menurut Foucault (2002: 54) wacana memiliki kekuatan praktis yang dapat mengatur pola kehidupan masyarakat dengan wacananya. 
Tafsir Al-Qur'an Tematik berupaya untuk menormalisasi ketidakdisiplinan suami-istri dalam relasi rumah tangga, misalnya tanggung jawab dalam membentuk keluarga sakinah dan menciptakan generasi yangberkualitas. Dalam konteks ini, penafsiran tersebut menjadi suatu instrumen bagi kekuasaan untuk menormalisasi perilaku dan sikap suami-istri yang tidak disiplin dalam membangun rumah tangga. Relasi kuasa hadir di dalamnya dengan mengukuhkan dominasi negara dalam mengatur sikap dan perilaku masyarakat agar sejalan dengan agenda Pemerintah untuk menciptakan Indonesia yang aman, damai, adil, dan demokratis sebagaimana tertera dalam Peraturan Presiden Republik Indonesia Nomor 7 Tahun 2005 tentang Rencana Pembangunan Jangka Menengah Nasional (RPJMN) 2004-2009.

Sementara Tafsir Al-Qur'an Tematik (Kemenag RI, 2014: 276) mengkonstruksi kesetaraan gender yang menguatkan kepemimpinan perempuan setara dengan laki-laki dalam berperan aktif di ruang publik; sosial, ekonomi, pendidikan, budaya, dan politik. Dari sini wacana memproduksi pengetahuan sekaligus menciptakan kekuasaan, yakni pengetahuan tentang kesetaran gender sekaligus menciptakan kekuasaan bagi perempuan untuk berkiprah di ranah publik sebagaimana laki-laki. Dalam pandangan Foucault (1990: 105), kekuasaan bersifat produktif karena menciptakan konstelasi baru di masyarakat. Dengan wacana kesetaraan gender tersebut, menurut Jawad (1998: 11), eksistensi perempuan ditempatkan pada posisi yang memiliki hak yang sama dalam kepemimpinan publik, seperti: mengikuti pemilu, menjadi nominator, dan memperoleh jabatan politik. 
Penafsiran kepemimpinan perempuan sering dibenturkan dengan penafsiran terhadap QS. anNisa'[4]: 34. Dalam menafsirkan ayat tersebut, mayoritas ulama klasik sering memberikan penafsiran yang menempatkan perempuan pada posisi yang lebih rendah dari laki-laki. Menurut Syamsuddin (2009: 52), penafsiran yang sangat jelas bias gender misalnya terdapat pada penafsiran Ibn Katsir yang menempatkan laki-laki pada puncak superioritas sehingga pemimpin, pembesar, hakim, pendidik dan derajat kenabian hanya dimiliki oleh laki-laki.

At-Thabari (2000:59) mengkritisi kepemimpinan laki-laki atas perempuan tersebut tidak bersifat mutlak, karena hanya berlaku sepanjang pada hal yang diperintahkan oleh Allah. Keutamaan laki-laki atas perempuan juga bersifat fungsional, karena disebabkan oleh nafkah dan usaha yang dilakukan oleh para suami untuk istrinya. Al-Qurthubi (1999: 161) bahkan lebih keras lagi mengatakan, jika suami tidak mampu menafkahi perempuan, maka tidak berhak atas kepemimpinan keluarga dan istri berhak untuk menuntut pembatalan pernikahan karena tujuan pernikahan dianggap tidak mampu dicapai.

Dalam konteks ini, Tafsir Al-Qur'an Tematik (Kemenag RI, 2014: 276) sepakat dengan pendapat Jawad Mugmiyah dalam Tafsir al-Kasyif yang menegaskan bahwa ayat tersebut bukanlah menciptakan perbedaan yang dianggap perempuan itu lebih rendah dibanding laki-laki, tetapi hanyalah ditujukan kepada laki-laki sebagai suami dan perempuan sebagai istri, keduanya adalah rukun kehidupan tidak satu pun bisa hidup tanpa yang lain, keduanya saling melengkapi. Ayat ini hanya ditujukan 
untuk kepemimpinan suami saja, memimpin istrinya. Bukan untuk menjadi pemimpin secara umum dan bukan untuk menjadi penguasa yang diktator.

Tafsir Al-Qur'an Tematik (Kemenag RI, 2014: 277) mengkonstruksi penafsiran yang melahirkan pengetahuan tentang kepemimpinan perempuan sebagai kepala negara dapat berjalan dengan baik jika sistem pemerintahan berdasarkan musyawarah, dimana dalam menjalankan tugasnya sebagai pemimpin dibantu oleh tenaga-tenaga ahli sesuai bidangnya masing-masing (menteri-menteri) dan ditopang dengan alat-alat canggih.Pemahaman ini sejalan dengan pandangan Mulia (2005: 275) yang menegaskan bahwa keterlibatan perempuan di dunia politik bukan dimaksudkan untuk menjatuhkan, menurunkan, atau merebut kekuasaan dari tangan laki-laki, melainkan dimaksudkan agar bisa menjadi mitra sejajar laki-laki.Dalam konteks ini, secara perlahan, mufassir dengan produk penafsirannya akan memapankan diri dengan mengatasnamakan keilmiahan, sehingga subjek yang memaksa (mufassir) seolah-olah hilang di balik kriteria keilmiahan tesebut (Haryatmoko, 2010: 10-11) yang tersisa hanyalah keyakinan bahwa yang didukung, dibela, dan dipatuhi bukanlah mufassir ataupun produk tafsirnya melainkan ajaran Al-Qur'an atau ajaran agama.

Tafsir Al-Qur'an Tematik juga mengkonstruksi penafsiran dengan mengatur pola interaksi di masyarakat. Relasi gender antara kaum perempuan dan laki-laki dibangun setara dalam mengemban tugas sosial kemasyarakatannya, yakni saling membantu, saling melengkapi, saling tolongmenolong, dan saling bersinergi antara satu dengan 
yang lainnya guna mencapai kesejahteraan bersama. Dalam konteks ini,meminjam pendapat Carrette (2011: 43), akanterlihat bagaimana wacana yang dibangun memainkan peran penting dalam mengatur pola hidup masyarakat.

Tafsir Al-Qur'an Tematik (Kemenag RI, 2014: 45) mengkonstruksi pola kepemimpinan perempuan dengan mengatur pola kepemimpinan perempuan di masyarakat dan menetapkan di wilayah mana saja kepemimpinan perempuan sebaiknya diterapkan. Dalam konteks ini, penafsiran tersebut dapat memarjinalisasi peran gender di masyarakat. Dari sudut pandang inilah, menurut perspektif Foucault (2002: 51), penafsiran memiliki kekuatan praktis yang dapat mengatur pola kepemimpinan perempuan di masyarakat sesuai dengan kemampuan alamiahnya.

Tafsir Al-Qur'an Tematik melakukan pendisiplinan dan normalisasi dalam bentuk pengarahan sikap dan perilaku perempuan. Jika dipahami dari redaksi penafsirannya, pendisiplinan itu bertujuan untuk meningkatkan produktivitas peran perempuan di bidang sosial sebagaimana kaum laki-laki. Hal ini dapat ditemukan ketika menafsirkan QS.at-Taubah [9]: 71 sebagaimana berikut.

“.....dalam tugas sosial kemasyarakatan (amar makruf nahi munkar) kaum perempuan dan lakilaki harus saling membantu, saling melengkapi dan saling ber-ta'awun (tolong-menolong), serta bersinergi antara satu dengan yang lainnya. Bersinergi dan ber-ta'awun dalam membangun masyarakat yang sejahtera atas dasar nilai-nilai ajaran Islam, dalam berbagai bidang kehidupan, seperti sosial ekonomi, pendidikan, budaya, dan 
lain sebagainya." (Kemenag RI, 2014: 44-45)

Tafsir Al-Qur'an Tematik juga mengarahkan perilaku gender sekaligus pembatasan ketika perempuan beraktivitas di ruang publik, sehingga menjadi selfcontrol bagi perempuan dalam kondisi kepatuhan nirsadar gender.Dalam perspektif teori relasi kuasa, wacana tafsir tentang kedudukan dan peran perempuan tersebut bukannya tanpa tujuan, berbagai kepentingan hadir di dalamnya dan membangun beragam relasi untuk mengatur, mengarahkan, memposisikan perempuan supaya setara dengan laki-laki. Dalam konteks ini, menurut penulis, mufassir berada di antara dua posisi, pertama mufassir diarahkan agar sejalan dengan kehendak dan kepentingan negara dalam mewujudkan Indonesia yang aman tentram dan damai, sebagaimana terekam dalam Sambutan Menteri Agama dan Badan Litbang dan Diklat Departemen Agama RI pada Penerbitan Tafsir Al-Qur'an Tematik (Kemenag RI, 2014: 9-12); dan Kedua, Mufassir baik secara sadar atau tidakmeminjam istilah Foucaut-telah didominasi, dihegemoni, dikontrol oleh wacana dalam agenda Pemerintah, untuk selanjutnya mufassir juga melalui wacana tafsirnya telah mendominasi, menghegemoni, mengontrol dan mengarahkan perilaku politik setiap individu untuk mematuhi produk tafsirnya.

\section{Relasi Kuasa Tafsir Al-Qur'an Tematik: Mulai dari Wacana Pengetahuan, Konstruksi Kesetaraan, Hingga Hegemoni Pengetahuan}

Kitab Tafsir Al-Qur'an Tematik disusun oleh tim tafsir Lajnah Pentashihan Mushaf Al-Qur'an, Kementerian Agama Republik Indonesiamenghadirkan sejumlah 
tema-tema gender, di antaranya: tema pemberdayaan perempuan, kedudukan dan peran perempuan, serta perempuan dan ketenagakerjaan (Kemenag RI, 2014: 282302). Tema-tema tersebut membuktikan adanya perhatian khusus para mufassir terhadap kesetaraan gender di Indonesia. Keterlibatan tersebut menunjukkan adanya strategi kekuasaan untuk menyeragamkan masyarakat Indonesia yang plural. Dengan stateginya, mufassir menormalisasi pola relasi antara laki-laki dan perempuan dalam etika bergaul, etika berpakaian, dan lain-lain. Keterlibatan ini juga menggambarkan kontrol mufassir terhadap kehidupan umat Islam agar sejalan dengan tujuan-tujuan pembangunan di Indonesia dan sekaligus sebagai bentuk kontrol panoptikon dalam mengawal pemahaman terhadap teks-teks keagamaan dengan menetapkan standar yang dipandang benar dan baik, sehingga pemahaman umat terhindar dari segala bentuk penyelewengan dan penyimpangan. Dalam konteks ini, kontrol yang paling efektif dengan instrumen wacana tafsir yang dikontruksi lewat lembaga keagamaan (Haryatmoko, 2002: 16). Dalam konteks ini,Tafsir Al-Qur'an Tematik karya Lembaga Pentashihan Mushaf Al-Qur'an dapat menjadi instrumen yang paling efektif untuk mengkontrusi dan menormalisasi kehidupan umat muslim..

Kesetaraan genderyang dikonstruksi oleh Tafsir AlQur'an Tematik Kementerian Agama RI sebagai pihak yang memilikiotoritas di Indonesia bertujuan agar masyarakat Indonesia mengikuti atau mematuhinya. Kekuasaan bukan milik Pemerintah sepenuhnya tetapi kekuasaan adalah strategi untuk menguasai pihak lain melalui wacana tafsir yang dikeluarkan Kementerian Agama RI/Pemerintah. Berdasarkan hal itu, kekuasaan dan wacana tafsir keduanya saling terkait (Haryatmoko, 2013: 41). Semua pengetahuan, tidak menutup tafsir Al-Qur'an, sarat dengan politik 
kekuasaan. Hubungan-hubungan kekuasaan bersumber dari wacana penafsiran yang dibentuk. Wacana ini dianggap menjadi pengetahuan ilmiah dan kemudian dipandang sebagai kebenaran hakiki setelah mendapat legitimasi Pemerintah.

Wacana tafsir di bawah pengawasan Kemenag RI secara sistematis menandai sejarah strategi perubahan hubungan kekuasaan dan kebenaran. Strategi kekuasaan melahirkan bentuk wacana yang bisa mengatur hubungan kekuasaan dengan masyarakat, seperti larangan, penafian, atau sensor terhadap perilaku-perilaku yang dianggap menyimpang, tidak sesuai norma, tidak sesuai kodrat, dan hal-hal lain yang dianggap tidak meningkatkan produktivitas. Dalam konteks ini, kekuasaan mengalir pada setiap adanya hubungan dan kekuasaan melekat pada proses penafsiran itu sendiri. Dalam situasi seperti ini, mufassir berada pada pihak yang ikut ambil bagian dalam proses penafsiran untuk menciptakan wacana sesuai kehendak pengusungnya. Sedangkan masyarakat muslim, baik laki-laki maupun perempuan, adalah sasaran atau korban yang bisa jadi diuntungkan karena wacana kesetaraan gender yang dikontruksi mampu mengangkat posisi salah satu dipihak yang selama ini tidak diperlakukan setara atau justeru sebaliknya menderita akibat proses penafsiran yang tidak mengusung egaliterianisme dalam penafsirannya.

Penafsiran tentang pemberdayaan perempuan, kedudukan dan peran perempuan, serta perempuan dan ketenagakerjaan dalam Kitab Tafsir Al-Qur'an Tematik dari sudut pandangnya menunjukkan besarnya kepentingan yang terlibat, baik oleh penguasa, mufassir, dan pada saat yang sama budaya patriarkhi memang telah lama mengakar kuat dalam kehidupan masyarakat Indonesia. Hal ini 
menunjukkan pula bahwa institusi kekuasaan (Kemenag RI) memiliki kepentingan besar untuk mengatur kehidupan umat Islam agar sejalan dengan agenda Pemerintah dalam mewujudkan Indonesia yang aman, damai dan sejahtera lewat ajaran agama yang termanifestasikan dalam kitab Tafsir Al-Qur'an Tematik.

Berbagai bentuk aturan dan norma menjadi mekanisme strategis dalam mengokohkan kekuasaan pengetahuan tentang kenormalan kesetaraan gender. Dengan adanya bentuk aturan dannorma yang dikonstruksi, penyeragaman perilaku umat menjadi lebih mudah dilakukan dan dilanggengkan dengan norma dan aturan yang secara sadar dianggap sebagai sebuah ajaran agama yang harus diamalkan.

Berbagai strategi kekuasaan diterapkan untuk mengatur kehidupan masyarakat lewat pengetahuan tafsir. Dalam penafsiran kitab tersebut misalnya, strategi kekuasaan-pengetahuan memproduksi kebenaran dengan menghisterisasi tubuh perempuan yang tidak bisa dilepaskan dari tanggung jawab biologis dan moral. Tanggung jawab biologis ini tampak pada penguatan peran perempuan (istri) sebagai pasangan biologis bagi laki-laki (suami); sedangkan tanggung jawab moral tampak pada histerisasi tubuh perempuan sebagai institusi utama dalam pembentukan akhlak anak. Perempuan meski diperbolehkan berkiprah di ruang publik, namun selalu dibebani dengan tanggung jawab biologi dan moral dengan alasan untuk melahirkan generasi yang unggul (saleh). Dengan histerisasi tersebut, strategi kekuasaan secara terorganisir telah mengkonstruksi perempuan. Kendatipun demikian, kuasa-pengetahuan secara tersembunyi juga mengorganisir laki-laki (suami) untuk bertanggung jawab secara material dan moral untuk mewujudkan keluarga 
yang harmonis.

Produk Tafsir Al-Qur'an Tematik merupakan wujud nyata bagaimana sebuah pengetahuan dikonstruksi guna mengembalikan wacana pengetahuan yang telah berlangsung dan dilanggengkan oleh konstruksi tafsir yang cenderung patriarkis menjadi non-patriarkis. Hadirnya kitab Tafsir Al-Qur'an Tematik ini semakin mengukuhkan peran agama sebagai penjaga moralitas umat. Melarang dan menolak perilaku tertentu yang tidak sejalan dengan ajaran agama menjadi bagian dari tugas agama untuk menormalisasinya. Dengan agama, individu dan masyarakat diatur melalui penyeragaman perilaku, bahasa, pakaian maupun ritus. Penyeragaman ini menjadi teknik kekuasaan yang akan menghasilkan identitas dan memudahkan agama agar dipatuhi oleh penganutnya, ataupun ditakuti oleh pemeluk yang tidak termasuk dalam bagiannya (Haryatmoko, 2013:39-40).

Konstruksi gender dalam Tafsir Al-Qur'an Tematik diproduksi dalam pergumulan interaksi dengan agama, nuansa budaya, serta kondisi sosial ekonomi politik di Indonesia. Konstruksi yang muncul berupa persoalan peran, status dan relasi sosial yang kemudian memunculkan identitas dan peran gender yang seharusnya bagi laki-laki dan perempuan dalam relasi sosial. Identitas dan peran gender ini terlihat dalam norma, etika, dan tata nilai yang dilegitimasi oleh Tafsir Al-Qur'an Tematik. Dari pembacaan dengan kaca mata gender tersebut dapat dipahami bahwa kitab tersebut membangun relasi kesetaraan gender melalui normalisasi. Hal ini dapat ditemukan pada beberapa penafsiran yang masih diskriminasi terhadap kepemimpinan perempuan, bahkan telah memarjinalisasi perempuan dengan menempatkan laki-laki pada posisi lebih layak, lebih paham, dan lebih siap memimpin 
ketimbang perempuan (Kemenag RI, 2014: 46). Dalam konteks ini, kekuasan bergerak secara dinamis dengan menciptakan hubungan yang tidak setara antara laki-laki dan perempuan. Dalam pandangan Foucault (1990:11-12), kekuasaan hadir di setiap perbedaan untuk melanggengkan dominasi partiarkhi, seperti penafsiran berikut ini.

“.....sesungguhnya akan lebih maslahat bagi suatu bangsa apabila kepala negara/kepala daerah seorang laki-laki yang adil, jujur, tegas, berpihak kepada kepentingan masyarakat, visioner, memiliki keluasan ilmu pengetahuan, sekaligus memiliki kesehatan jasmani yang prima. Sehingga tugas dan kewajibannya sebagai pemimpin bisa dilaksanakan dengan baik dan optimal" (Kemenag RI, 2014: 47).

“Oleh sebab itu boleh saja wanita menjadi kepala negara, yang penting adalah bahwa seorang wanita yangdiangkatuntukmendudukijabatanitumemenuhi kriteria syarat-syarat yang telah disebutkan di atas. Tentu saja dalam hal ini selama masih ada kaum pria yang lebih layak, maka sebaiknya jabatan tersebut diserahkan saja kepada kaum pria"(Kemenag RI, 2014:277).

Dua penafsiran di atasmenunjukkan adanya dualisme pemikiran dalam penafsiran kitab tafsir tersebut. Di satu sisi, penafsiran tersebut memberikan kesempatan dan hak yang setara bagi perempuan untuk berprofesi dalam bidang apapun, bahkan menjadi top leader. Di sisi lain, penafsiran tersebut juga membatasi semuanya dengan pernyataannya yang kontradiktif. Dengan begitu, produk pemikiran mufassir di dalamnya berlabuh kuasapengetahuan yang secara tersamar membentuk pola pikir 
yang tekstualis karena hanya mampu melahirkan produk tafsir yang masih bias gender. Padahal seharusnya, relasi kuasa pengetahuan beroperasi dengan konteks dalam mendefinisikan kesetaraan gender dengan mengubah relasi laki-laki dan perempuan yang lebih egaliter dalam konstelasi sosial.

\section{Simpulan}

Kesetaraan hak gender yang dikonstruksi dalam kitab Tafsir Al-Qur'an Tematik memperlihatkan bahwa perempuan disetarakan dengan laki-laki dalam hak bekerja dan perlindungan kerja, hak kemandirian ekonomi, hak pendidikan tinggi, hak hidup sehat, dan hak kepemimpinan. Dengan wacananya, relasi kuasapengetahuan beroperasi secara sistematis dengan mengontrol hubungan kekuasaan dengan kebenaran guna mengatur kehidupan umat agar produktif dan sejalan dengan agenda pemerintah. Sebagai catatan dari penulis, kesetaraan gender yang dikonstruksi tidak serta merta murni penafsiran, akan tetapi kekuasaan ada di dalamnya saling terkait dengan produk tafsir yang sarat dengan politik kekuasaan. Kontestasi ide, gagasan, dan pemikiran para mufassir tidak sepenuhnya mampu menetralisir efek diskriminatif dalam sejumlah penafsiran yang masih bias gender karena lebih memprioritaskan kaum laki-laki dalam kepemimpinan di ranah politik dan lebih menekankan kaum perempuan untuk konsentrasi pada tugas utamanya di ruang domestik. 


\section{DAFTAR PUSTAKA}

Al Munawar, S. A. 2002. Al-Qur'an Membangun Tradisi Kesalehan Hakiki. Jakarta: Ciputat Press.

Almirzanah, S. dan Syamsuddin, S. (edt.), 2009, Upaya Integrasi Hermeneutika dalam Kajian Qur'an dan Hadis: Teori dan Aplikasi, Yogyakarta: Lembaga Penelitian UIN Sunan Kalijaga Yogyakarta,

Al-Qurthubi, Abu 'Abdillah Muhammad bin Ahmad alAnshariyyi, 1999,Jami' li Ahkamil-Qur'an, Beirut: Dar al-fikr,

Ar-Rumi, Fahd ibn 'Abdurrahman ibn Sulaiman, 2002, Ittijahat at-Tafsir fi al-Qarn ar-Rabi'. Cet. Ke-4. Riyad: Maktabah ar-Rasyad.

At-Thabari, Muhammad bin Jarir bin Yazid Abu Ja'far, 2000, Jami'ul Bayan fi Takwilil-Qur'an, Riyad: Mu'assasah arRisalah.

Carrette, Jereme R., 2011, “Prolog kepada Pengakuan Daging" dalam Agama, Seksualitas, Kebudayaan: Esai, Kuliah dan Wawancara Terpilih Foucault, ed. Jereme R. Carrette, terj. Indi Aunullah,Yogyakarta: Jalasutra.

Crawley,1931, Dress, Drinks, and Drums: FurtherStudies of Savages and Sex, peny. :TheodoreBesterman, London: Methuen.

Dzuhayatin, S. R., 2015, Rezim Gender Muhammadiyah: Kontestasi Gender, Identitas, dan Eksistensi. Yogyakarta: Suka Press UIN Sunan Kalijaga bekerja sama dengan Pustaka Pelajar.

Guindi,FadwaEl, 1999, Jilbab antara Kesalehan, Kesopanan, danPerlawanan, terj. Mujiburrahman, Jakarta: PT. Serambi Ilmu Semesta.

Federspiel, H. M., 1996, Kajian al-Qur'an di Indonesia dari Mahmud Yunus hingga Quraish Shihab. Bandung: 
Mizan.

Foucault, M., 1977, Discipline and Punish: The Birth of the Prison, trans. Alan Seridan. England: Penguin Books.

Press , 1980,Power/Knowledge, Brighton, UK: Harvester 1990, The History of Sexuality, Vol. I: An Introduction. Terj. Robert Hurley. New York: Vintage Books. -, 2002,Archaelogy of Knowledge,Terj. A.M. Sheridan Smith. London and New York: Routledge Classics.

Gusmian, I., 2003, Khazanah Tafsir Indonesia: dari Hermeneutika hingga Ideologi, Jakarta: Teraju.

Haryatmoko, 2013, “Sejarah Seksualitas: Sejarah

Pewacanaan Seks dan Kekuasaan Menurut Foucault" dalam Christina Siwi Handayani dkk., Subyek yang Dikekang, Jakarta: Komunitas Salihara. 2010, Dominasi Penuh Muslihat: Akar kekerasan dan Diskriminasi, Jakarta: Gramedia Pustaka Utama, Ilyas, Y., 2005, Konstruksi Pemikiran Genderdalam Pemikiran Mufassir, Jakarta: Program Peningkatan Kualitas Pelayanan Publik, Ditjen Bimas Islam dan Penyelenggaraan Haji.

Jawad, H. A, 1998, The Rights of Women in Islam: an Authentic Approach. New York: ST. Martin's Press, INC.

Kementerian Agama Republik Indonesia, 2004, Tafsir Tematik al-Qur'an, Jakarta: Kemenag Press.

Lerner, K Lee, Brenda Wilmoth Lerner dkk., 2006, Gender Issues and Sexuality: Essential Primary Sources.USA: Thomson Corporation.

Mannheim, K. tt., Ideology and Utopia, an Introduction to the Sociology of Knowledge. London: Routledge \& Kegan Paul Ltd. 39.

Mudhoffir, A. M., 2013, “Teori kekuasaan Foucault”, Jurnal 
Sosiologi MASYARAKAT 18, No. 1.

Mulia, S. M., 2005, Muslimah Reformis: Perempuan Pembaru Keagamaan. Bandung: Mizan.

Rohmaniyah, I., 2014, Konstruksi Patriarki dalam Tafsir Agama: Sebuah Jalan Panjang.Yogyakarta: Fakultas Ushuluddin dan Pemikiran Islam bekerjasama dengan Diandra Pustaka Indonesia,.

Schneider, E. M., 2009, “Domestic Violence, Citizenship, and Equality" dalam Linda C McClain and Joanna L. Grossman (edt.), Gender Equality: Dimensions of Women's Equal Citizenship. New York: Cambridge University Press.

Shihab, U., 2005, Kontekstualitas al-Qur'an: Kajian Tematik Atas Ayat-ayat Hukum dalam al-Qur'an, Jakarta: Penamadani.

Song, S., 2007, Justice and Multiculturalism: An Egalitarian Argument for Cultural Accommodation, New York: Cambridge University Press.

Subhan, Z. 1999, Tafsir Kebencian: Studi Bias Gender dalam Tafsir al-Qur'an. Yogyakarta: LKiS.

Syamsuddin, Sahiron, 2009,Tafsir Studies, Yogyakarta: Elsaq Press.

Ulya, 2016, “Pewacanaan Ulu al-Amr QS.an-Nisa[4]: 59 Pada Tafsir al-Azhar: Memotret Diskusi Dasar Negara Indonesia Tahun 1955-1966", Disertasi, Yogyakarta: Pascasarjana UIN Sunan Kalijaga,

Umar, N., 1999, Argumen Kesetaraan Jender Perspektif alQur'an, Jakarta: Paramadina.

United Nations Development Programme, 2005, Taking Action: Achieving Gender Equality and Empowering Women. New York: United Nations Development Programme. 
Wienclaw, R.A., 2011, "Gender and Domestic Responsibilities" dalam The Editors of Saleem Press, Gender Roles and Equality. California: Salem Press.

Zayd, N. H. A., 2003. Dekonstruksi Gender. Terj. Moch. Nur Ichwan dan Moch. Syamsul Hadi. Yogyakarta: Samha bekerjasama dengan PSW IAIN Sunan SUKA dan McGill.

http:/ / www.kompasiana.com (diakses 05 Januari 2016).

http://www.hukumonline.com, Rancangan Undangundang Republik Indonesia tentang Kesetaraan dan keadilan Gender (KKG), (diakses 16 Oktober 2016).

http://www.komnasperempuan.go.id. "Mewujudkan Payung Hukum dan Penghapusan Diskriminasi Gender di Indonesia: Prinsip-Prinsip Usulan Terhadap RUU Kesetaraan dan Keadilan Gender." (diakses 17 Oktober 2016).

Peraturan Presiden Republik Indonesia Nomor7Tahun 2005 tentang Rencana Pembangunan Jangka Menengah Nasional (RPJMN) 2004-2009, bagian II dan III. 